\title{
MODEL DINAMIK TINGKAT KERENTANAN PANTAI PULAU POTERAN DAN GILI LAWAK KABUPATEN SUMENEP MADURA
}

\author{
DYNAMICS MODEL OF COASTAL VULNERABILITY OF POTERAN AND GILI LAWAK \\ ISLAND, SUMENEP, MADURA
}

\author{
Maulinna K. Wardhani ${ }^{1 *}$, Akhmad Farid ${ }^{2}$ \\ ${ }^{1}$ Program Studi IImu Kelautan, Universitas Trunojoyo Madura \\ ${ }^{2}$ Program Studi Manajemen Sumberdaya Perairan, Universitas Trunojoyo Madura \\ "Corresponding author e-mail: maulinna@gmail.com
}

Submitted: 24 Desember 2016 / Revised: 26 April 2017 / Accepted: 26 April 2017

http://doi.org/10.21107/jk.v10i1.2427

\begin{abstract}
Poteran and Gili Lawak Island Sumenep Regency is a small islands that located in the west of Madura with potential terrestrial and marine areas. The purpose of this research is the dynamic modeling of coastal vulnerability of small islands are based on ecological, social and economic as an initial effort determine the sustainable management planning and mapping. The analysis will be performed in this study is the determination of variables coastal vulnerability index for small islands and the dynamics models of the vulnerability for coastal islands. These variables include, (1) Exposure, (2) Sensitivity and (3) Adaptive Capacity. The development model of dynamic simulation was done to evaluate the beach vulnerability on the Poteran and Gili Lawak Island at Talango District Sumenep based on several assumptions, they are (1) the model was in a state of permanent or stable (steady state), (2) the model considered a closed system. Mean sea level rise per year, erosion rate and population density are dynamic parameters that causes high of vulnerability value in Pulau Poteran, while the sea-grass parameter on Gili Lawak Island causes the value of adaptive capasity demention is higher than other dimensions. The level of beach vulnerability of Poteran and Gili Lawak Island at middle category and was based on a dynamic model created two islands will be at a very high level of vulnerability in the third yearif not increase the adaptive capacity of coastal habitats.
\end{abstract}

Keywords: Dynamic Model, Beach Vulnerability, Small Island

\section{ABSTRAK}

Pulau Poteran dan Pulau Gili Lawak Kabupaten Sumenep merupakan pulau-pulau kecil yang berada di sebelah barat Pulau Madura dengan kawasan darat dan perairan yang cukup potensial. Tujuan dari penelitian ini adalah pembuatan model dinamik kerentanan pantai pulau-pulau kecil tersebut berdasarkan aspek ekologi, sosial dan ekonomi sebagai upaya awal menetukan perencanaan pengelolaan yang berkelanjutan dan memetakannya. Analisis yang akan dilakukan pada penelitian ini merupakan penetapan variabel-variabel indeks kerentanan pantai pulau-pulau kecil (PPK) dan memodelkan dinamika kerentanan pantai pulau-pulau tersebut. Variabel-variabel tersebut meliputi, (1) Keterpaparan (Exposure), (2) Kepekaan (Sensitivity) dan (3) Daya Adaptasi (Adaptive Capacity). Pengembangan model simulasi dinamis ini bertujuan untuk mempelajari tingkat kerentanan pantai di Pulau Poteran dan Gili Lawak Kecamatan Talango Kabupaten Sumenep didasarkan pada beberapa asumsi, yaitu: (1) model tersebut berada dalam kondisi tetap atau stabil (steady state), (2) model tersebut dianggap suatu sistem yang tertutup (closed system). Parameter kenaikan muka laut rata-rata tiap tahun, tingkat erosi dan kepadatan penduduk merupakan parameter dinamik yang menyebabkan nilai kerentanan tinggi di Pulau Poteran, sedangkan parameter lamun mengakibatkan dimensi daya adaptif diPulau Gili Lawak menjadi lebih tinggi dari dimensi yang lain. Tingkat kerentanan pantai Pulau Poteran dan Gili Lawak berada pada kategori sedang dan berdasarkan model dinamik yang dibuat kedua pulau tersebut akan berada 
pada tingkat kerentanan sangat tinggi pada tahun ke 3 jika tidak dilakukan peningkatan kapasitas adaptif habitat pesisir.

Kata Kunci: Model Dinamik, Kerentanan, Pulau Kecil

\section{PENDAHULUAN}

Pulau Poteran dan Gili Lawak merupakan pulau-pulau kecil di Kecamatan Talango Kabupaten Sumenep yang memiliki perairan yang cukup potensial. Perairan tersebut tidak hanya dimanfaatkan sebagai daerah penangkapan ikan oleh penduduk lokal, tetapi juga potensi wisata bahari. Kegiatankegiatan tersebut menjadi tantangan pengelolaan kawasan menghadapi ancaman ekologi, ekonomi dan sosial. Hal ini dikarenakan pulau-pulau kecil (PPK) diisukan sebagai wilayah yang lemah dan rentan oleh faktor lingkungan, ekonomi dan sosial (Pratt et al., 2004).

Pulau Poteran dan Gili Lawak dengan lahan yang terbatas di dalam perairan yang luas, tentunya memiliki berbagai permasalahan yang dihadapi dalam pengelolaannya. Hal tersebut merupakan atribut kerentanan yang bersifat endogenous. Selain itu, berbagai tekanan yang bersifat exogenous secara alamiah maupun antropogenik juga merupakan masalah utama pengelolaan PPK. Dengan demikian, pengelolaan PPK secara terpadu pada kawasan ini bukan semata-mata ditujukan untuk kepentingan kelestarian sumberdaya alam saja, tetapi juga keberlanjutan masyarakata PPK. Hal ini dikarenakan keduanya merupakan bagian dari sistem ekologi dan sistem sosialekonomi yang penting dalam keberadaan pulau-pulau kecil. Penempatan komponen lingkungan dalam hal ini merupakan faktor penyeimbang dari berbagai kegiatan pengembangan yang telah dan akan dilakukan. Berdasarkan hal tersebut, diperlukan model dinamik terhadap kerentanan pantai di Pulau Poteran dan Gili Lawak tersebut berdasarkan aspek ekologi sebagai upaya awal menetukan perencanaan pengelolaan yang berkelanjutan. Berdasarkan uraian di atas penelitian ini bertujuan menganalisis tingkat kerentanan pantai Pulau Poteran dan Gili Lawak di Kecamatan Talango Kabupaten Sumenep dan memodelkan dinamika kerentanannya selama 30 tahun.

\section{MATERI DAN METODE}

\section{Waktu dan Tempat Penelitian}

Penelitian ini berlokasi di Pulau Poteran dan Gili Lawak Kecamatan Talango Kabupaten Sumenep Propinsi Jawa Timur pada bulan Maret-Agustus 2016.

\section{Metode Penelitian}

Data yang dikumpulkan dalam penelitian ini merupakan data yang berkaitan dengan variabel indikator kerentanan PPK diambil berdasarkan rujukan variabel kerentanan pantai yang diadopsi dari Polsky et al (2007). Variabel dan indikator kerentanan ini disesuaikan dengan karakteristik masingmasing pulau-pulau kecil (Adrianto, 2005). Selain itu, variabel dan indikator kerentanan juga didasarkan pada pertimbangan ketersediaan data yang cukup dan tingkat keterpentingan variabel dalam indeks kerentanan. Data yang akan dikumpulkan dalam penelitian ini meliputi data primer dan sekunder. Berdasarkan kondisi PPK di Kecamatan Talango Kabupaten Sumenep, potensi ancaman bahaya bagi keberlanjutan pembangunan dan pengembangan PPK tersebut dapat dikelompokkan berdasarkan sumbernya, yaitu fenomena alamiah (natural disaster), karakteristik sifat pulau dan ancaman yang bersifat antropogenik. Oleh karena itu, indeks kerentanan PPK di Kecamatan Talango Kabupaten Sumenep merupakan indeks kerentanan gabungan yang dibangun dari variabel-variabel lingkungan dan sosial-ekonomi yang memiliki pengaruh secara eksternal pada PPK tersebut. Variabel-variabel tersebut didapatkan dari data survei lapang, pengolahan citra dan wawancara. Data Survei lapang diambil untuk melihat kondisi saat ini dari pulau-pulau kecil kawasan penelitian. Sedangkan data citra digunakan untuk mendapatkan data dinamik perubahan lingkungan dari tahun 2005 sampai tahun 2015. Data sosial didapatkan melalui teknik wawancara. Variabel-variabel tersebut meliputi: 
a. Keterpaparan (exposure)

Variabel keterpaparan (exposure) terdiri atas 1) dinamika pesisir yang meliputi tinggi permukaan air laut (sea level rise), pasang surut, erosi, 2) gangguan alam (tsunami) selama 100 tahun terakhir), 3) pertumbuhan penduduk dan kepadatan penduduk.

b. Kepekaan (sensitivity)

Variabel kepekaan (sensitivity) dibentuk berdasarkan 1) karakteristik pantai, yaitu elevasi, kemiringan dan tipologi, 2) penggunaan lahan dan 3) jarak pemukiman penduduk dengan pantai.

c. Daya adaptasi (adaptive capacity) Variabel daya adaptasi (adaptive capacity) terdiri atas dua kriteria, yaitu 1) habitat pesisir yang meliputi persen tutupan terumbu karang hidup, persen tutupan lamun dan mangrove, dan 2) kawasan konservasi.

\section{Analisis Tingkat Kerentanan Pantai}

Dimensi kerentanan diidentifikasi menggunakan konsep Vulnerability Scoping Diagram (VSD) atau diagram pelingkupan kerentanan yang diadopsi dari Polsky et al. (2007) dan terdiri dari keterpaparan (exposure), kepekaan (sensitivity) dan daya adaptasi (adaptive capacity). Skala setiap parameter dalam masing-masing dimensi dimodifikasi dari Tahir (2009) dengan analisis indeks kerentanan pantai sebagai berikut (Tahir, 2010):

Dimensi keterpaparan (exposure) $\mathrm{IE}=0,41(\mathrm{SR} \times \mathrm{ER})+0,21(\mathrm{GL})+0,14(\mathrm{PS})$ $+0,14 \mathrm{TS}+0,10(\mathrm{PD} \times \mathrm{KD})$

Keterangan:

IE : Indeks keterpaparan

$\mathrm{SR} \quad$ : tinggi permukaan air laut

ER : erosi

GL : tinggi gelombang

PS : amplitudo pasang surut

TS : gangguan alam

PD : pertumbuhan penduduk

KD : kepadatan penduduk

Dimensi kepekaan (sensitivity)

$\mathrm{IS}=0,43(\mathrm{EL})+0,21(\mathrm{TP})+0,14(\mathrm{SL})+0,11$

$(\mathrm{PL})+0,11(\mathrm{PP}) . .(2)$

Keterangan

IS : Indeks kepekaan

EL : elevasi

TP : tipologi

SL : kemiringan lahan

$\mathrm{PL} \quad$ : penggunaan lahan
PP : jarak dengan pemukiman

Dimensi daya adaptasi (adaptive capacity)

$\mathrm{IAC}=0,40 \mathrm{HP}+0,20 \mathrm{TK}+0,20 \mathrm{MR}+0,11$

$\mathrm{LM}+0,11 \mathrm{KL}$

Keterangan

IAC : Indeks daya adaptasi (adaptive capacity)

HP : habitat pesisir

TK : terumbu karang

MR : mangrove

LM : lamun

$\mathrm{KL} \quad$ : kawasan konservasi

Formulasi indeks kerentanan juga diacu dari Tahir (2009) yang merupakan fungsi overlay dari ketiga dimensi di atas yang selanjutnya diekspresikan dalam persamaan matematika sebagai berikut:

$$
V=\frac{E \times S}{A C}
$$

Keterangan

$$
\begin{array}{ll}
\mathrm{V} & : \text { Kerentanan } \\
\mathrm{E} & \text { : Keterpaparan } \\
\mathrm{S} & \text { : Kepekaan } \\
\mathrm{AC} & \text { : Daya adaptasi }
\end{array}
$$

Dengan menggabungkan persamaan (1), (2) dan (3) ke dalam persamaan (4), diperoleh persamaan indeks kerentanan pantai (IKP) sebagai berikut:

$I K P=\frac{I E x I S}{I A C}$.

\section{HASIL DAN PEMBAHASAN}

\section{Parameter Kerentanan Pantai Pulau-pulau Kecil}

Penentuan tingkat kerentanan dilakukan melalui pendekatan penilaian terhadap parameter dengan skala tertentu yang dinyatakan sebagai nilai skor. Standarisasi keragaan data dan indikator ke dalam suatu unit yang sama dilakukan untuk menghasilkan indeks tunggal (Bossel, 1999) dan mereduksi seluruh komponen ke suatu nilai skoring pada beberapa tingkatan (Tahir, 2010). Penelitian ini menggunakan parameter yang digunakan Tahir (2010) yang modifikasi dan disesuaikan dengan karakteristik pulau-pulau kecil di Kecamatan Talango Kabupaten Sumenep menggunakan skala linkert. Hal ini dikarenakan parameter kerentanan pada masing-masing indeks kerentanan memiliki peran atau signifikansi yang berbeda terhadap nilai indeks kerentanan. Pemberian bobot lebih tinggi dilakukan untuk parameter dengan 
signifikansi yang lebih tinggi pula terhadap kerentanan pulau-pulau kecil (Rao et al., 2008 dan Daukakis, 2005) memberikan bobot yang lebih tinggi terhadap parameter yang memilki signifikansi yang lebih tinggi dibandingkan lainnya. Skala yang digunakan dalam penilaian (skoring) penelitian ini adalah 1 sampai 5 yang menunjukkan nilai dari tidak rentan sampai sangat rentan. Nilai minimum tingkat kerentanan dalam penelitian ini adalah 0,20 dan nilai maksimum 76,00 yang dibagi dalam 4 kelas kerentanan menggunakan skala linkert sebagai berikut (Doukakis, 2005):

0,20-6,04 : Kerentanan rendah (low)

6,05-18,18 : Kerentanan sedang (moderate)

$18,19-40,48$ : Kerentanan tinggi (high)

49,49 - 76,00: Kerentanan sangat tinggi (very high)

Tabel 1. Parameter Kerentanan Pantai Pulau Poteran dan Gili Lawak

\begin{tabular}{|c|c|c|c|c|c|}
\hline \multirow{2}{*}{ Parameter } & \multicolumn{5}{|c|}{ Nilai Skor } \\
\hline & 1 & 2 & 3 & 4 & 5 \\
\hline \multicolumn{6}{|l|}{ Exposure } \\
\hline $\begin{array}{l}\text { Kenaikan muka laut } \\
\text { (mm/thn) }\end{array}$ & $<4,99$ & $5-9,99$ & $10-14,99$ & $15-25$ & $>25$ \\
\hline Erosi Pantai (m/thn) & $>2.0$ & $1.0-2.0$ & $-1.0-1.0$ & $-1.0-(-2.0)$ & $<-2.0$ \\
\hline $\begin{array}{l}\text { Rata-rata tunggang } \\
\text { pasang }(\mathrm{m})\end{array}$ & $<0,50$ & $0,51-1,0$ & $1,1-2,0$ & $2,1-4,0$ & $>4$ \\
\hline Tinggi gelombang (m) & $\leq 0,50$ & $0,51-1$ & $1,1-1,5$ & $1,5-2$ & $>2$ \\
\hline $\begin{array}{l}\text { Kejadian tsunami yang } \\
\text { pernah terjadi }\end{array}$ & 0 & 1 & $2-3$ & $4-10$ & $>10$ \\
\hline $\begin{array}{l}\text { Pertumbuhan penduduk } \\
(\%)\end{array}$ & $<0,5$ & $0,5-1,0$ & $1,1-1,5$ & $1,6-2,0$ & $>2,0$ \\
\hline $\begin{array}{l}\text { Kepadatan penduduk } \\
\text { (jiwa/km2) }\end{array}$ & $<75$ & $76-150$ & $151-200$ & $201-400$ & $>400$ \\
\hline \multicolumn{6}{|l|}{ Sensivity } \\
\hline Elevasi (m) & $>5$ & $3.1-5$ & $2.1-3$ & $1.1-2$ & $<2$ \\
\hline Slope (\%) & $>40$ & $31-40$ & $16-30$ & $9-15$ & $0-8$ \\
\hline Tipologi pantai & bervegetasi & berbatu & berkikil & $\begin{array}{l}\text { pantai } \\
\text { berpasir }\end{array}$ & $\begin{array}{l}\text { pantai hasil } \\
\text { endapan }\end{array}$ \\
\hline Penggunaan lahan & $\begin{array}{l}\text { lahan } \\
\text { terbuka }\end{array}$ & udidaya laut & $\begin{array}{l}\text { budidaya } \\
\text { pertanian }\end{array}$ & pertanian & pemukiman \\
\hline $\begin{array}{l}\text { Jarak pemukiman } \\
\text { penduduk dengan } \\
\text { pantai (m) }\end{array}$ & $>2000$ & $1500-2000$ & $>1000-1500$ & $500-1000$ & $<500$ \\
\hline \multicolumn{6}{|l|}{ Adaptive capacity } \\
\hline $\begin{array}{l}\text { Habitat pesisir } \\
\text { (perbandingan luas } \\
\text { daratan pulau) }\end{array}$ & $\begin{array}{l}\text { lebih kecil } \\
\text { atau sama }\end{array}$ & $\begin{array}{l}2 \text { kali lebih } \\
\text { besar }\end{array}$ & $\begin{array}{l}3 \text { kali lebih } \\
\text { besar }\end{array}$ & $\begin{array}{l}4 \text { kali lebih } \\
\text { besar }\end{array}$ & $\begin{array}{c}>5 \text { kali } \\
\text { daratan } \\
\text { pulau }\end{array}$ \\
\hline Terumbu karang (\%) & $<20$ & $20-40$ & $>40-60$ & $>60-80$ & $>80$ \\
\hline Mangrove (NDVI) & $<-0.6$ & $-0.6-(-0.2)$ & $>-0.2-0.2$ & $>0.2-0.6$ & $>0.6$ \\
\hline Padang lamun (\%) & $<20$ & $20-40$ & $>40-60$ & $>60-80$ & $>80$ \\
\hline $\begin{array}{l}\text { Konservasi laut } \\
\text { (perbandingan } \\
\text { terhadap habitat } \\
\text { pesisir) }\end{array}$ & 0 & $1-10$ & $11-25$ & $26-40$ & $>50$ \\
\hline
\end{tabular}

Sumber: Modifikasi Tahir (2010) 
Tingkat Kerentanan Pantai Pulau Poteran dan Gili Lawak

Analisis tingkat kerentanan pantai pulaupulau kecil di Kecamatan Talango menunjukkan kedua pulau tersebut berada pada tingkat kerentanan sedang. Hal ini ditunjukkan beberapa parameter kerentanan lingkungan di kedua pulau ini sudah berada pada kategori sedang sampai tinggi terutama pada dimensi exposure. Parameter kerentanan pada dimensi exposure yang memiliki nilai skor yang tinggi adalah kenaikan permukaan laut, erosi dan kepadatan penduduk. Karakteristik pulaupulau kecil Kecamatan Talango sebagai pulau dengan subtrat pasir dan karang dengan slope landai menyebabkan nilai parameter kerentanan lingkungan untuk dimensi sensitivity menjadi tinggi. Hal ini diperparah dengan berbagai aktivitas yang merusak, seperti pertambangan pasir. Parameter-parameter dengan skor kerentanan yang tinggi pada dimensi exposure dan sensitivity menjadi perhatian dalam kaitan pengelolaan pulau-pulau kecil berkelanjutan.

Tabel 2. Tingkat Kerentanan Pantai Pulau Poteran dan Gili Lawak

\begin{tabular}{|c|c|c|c|c|}
\hline Parameter & $\begin{array}{c}\text { Hasil } \\
\text { Pengamatan } \\
\text { Pulau Poteran }\end{array}$ & Skor & $\begin{array}{l}\text { Hasil Pengamatan } \\
\text { Pulau Gili Lawak }\end{array}$ & Skor \\
\hline \multicolumn{5}{|l|}{ Exposure } \\
\hline Kenaikan muka laut (mm/thn) & 66,7 & 5 & 66,7 & 5 \\
\hline Erosi Pantai (m/thn) & $-35,032$ & 5 & 3,19 & 5 \\
\hline Rata-rata tunggang pasang $(\mathrm{m})$ & 1,00 & 2 & 1,00 & 2 \\
\hline Tinggi gelombang $(\mathrm{m})$ & 1,00 & 2 & 1,00 & 2 \\
\hline Kejadian tsunami yang pernah terjadi & 0 & 1 & 0 & 1 \\
\hline Pertumbuhan penduduk (\%) & 0,36 & 2 & 0,36 & 2 \\
\hline Kepadatan penduduk (jiwa/km2) & 763,42 & 5 & 763,42 & 5 \\
\hline \multicolumn{5}{|l|}{ Sensivity } \\
\hline Elevasi (m) & 8 & 1 & 8 & 1 \\
\hline Slope (\%) & 7 & 5 & 7 & 5 \\
\hline Tipologi pantai & $\begin{array}{l}\text { Pasir berbatu } \\
\text { sedikit vegetasi }\end{array}$ & 4 & $\begin{array}{l}\text { Pasir dengan } \\
\text { sedikit vegetasi }\end{array}$ & 4 \\
\hline Penggunaan lahan & Lahan kosong & 1 & Lahan kosong & 1 \\
\hline $\begin{array}{l}\text { Jarak pemukiman dengan garis pantai } \\
(\mathrm{m})\end{array}$ & 10 & 5 & 10 & 5 \\
\hline \multicolumn{5}{|l|}{ Adaptive capacity } \\
\hline $\begin{array}{l}\text { Habitat pesisir (perbandingan luas } \\
\text { daratan pulau) }\end{array}$ & 2 & 2 & 2 & 2 \\
\hline Terumbu karang (\%) & 55,38 & 3 & 51,12 & 3 \\
\hline Mangrove (NDVI) & $\begin{array}{l}-0.064535- \\
0.036760\end{array}$ & 3 & $\begin{array}{l}-0.073974- \\
0.046684\end{array}$ & 3 \\
\hline Padang lamun (\%) & $21 \%$ & 2 & 0 & 1 \\
\hline $\begin{array}{l}\text { Konservasi laut (perbandingan } \\
\text { terhadap habitat pesisir) }\end{array}$ & 0 & 1 & 0 & 1 \\
\hline IE & & 12,09 & & 12,09 \\
\hline IS & & 2.63 & & 2.63 \\
\hline IAC & & 2,33 & & 2,22 \\
\hline IKP & & 13,65 & & 14,32 \\
\hline
\end{tabular}




\section{Model Kerentanan Pantai Pulau-pulau Kecil Kecamatan Talango}

Pengembangan model simulasi dinamis ini bertujuan untuk mempelajari tingkat kerentanan pantai di KecamatanTalango Kabupaten Sumenep didasarkan pada beberapa asumsi, yaitu (1) model tersebut berada dalam kondisi tetap atau stabil (steady state), yang berarti selama waktu estimasi tidak terjadi perubahan-perubahan pada faktor yang bekerja dalam kompartemen, atau perubahan-perubahan yang terjadi tetap konstan sepanjang waktu; (2) model tersebut dianggap suatu sistem yang tertutup (closed system), yang berarti selama waktu estimasi tidak ada pengaruh faktor lain selain parameter yang digunakan dalam pemodelan tersebut. Model yang dikembangkan memperlihatkan hubungan fungsional dari setiap kompartemen dengan kompartemen lainnya serta faktor-faktor lingkungan yang bekerja pada setiap kompartemen. Kompartemen dalam model ini terdiri dari tiga variabel kondisi dan menggunakan data yang tersedia, yaitu keterpaparan (exposure), kepekaan (sensitivity) dan daya adaptasi (adaptive capacity).

Analisis kerentanan pantai mengacu kepada konsep yang dikembangkan oleh Turner et al. (2003) dengan kerentanan merupakan fungsi dari keterpaparan, kepekaan dan daya adaptasi dari suatu sistem pesisir. Identifikasi komponen kerentanan Polsky et al. (2007) mengembangkan model Vulnerability Scoping Diagram (Diagram Cakupan Kerentanan). Model VSD ini menempatkan keterpaparan, kepekaan dan daya adaptasi sebagai dimensi kerentanan. Selanjutnya dilakukan determinasi terhadap komponen dimensi kerentanan dan pengukuran komponen dimensi kerentanan. Berdasarkan parameter-parameter dalam tiga dimensi di atas tergambar model dinamik kerentanan pantai pulau-pulau kecil di Kecamatan Talango sebagaimana Gambar 1.

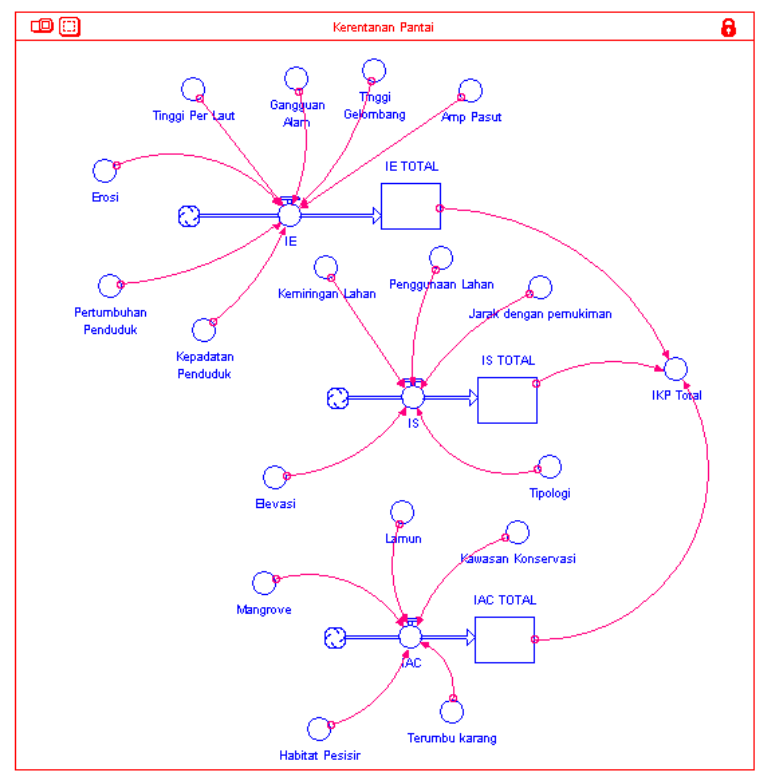

Gambar 1. Model Dinamik Kerentanan Pantai Pulau-pulau Kecil kecamatan Talango

Model yang dibanguan dalam penelitian ini merupakan model tanpa upaya perlakuan (pengelolaan) untuk mengurangi tingkat kerentanannya. Gambar 1 menunjukkan nilai indeks kerentanan pantai (IKP) terbagun atas nilai total indeks keterpaparan (IE), indeks kepekaan (IS) dan indeks daya adptif (IAC). Masing-masing nilai indeks tersebut dibangun dari parameter tinggi permukaan air laut, erosi, tinggi gelombang, amplitudo pasang surut, gangguan alam, pertumbuhan penduduk dan kepadatan penduduk untuk indeks keterpaparan/IE. Selanjutnya, indeks kepekaan (IS) dibangun dari parameter elevasi, tipologi, kemiringan lahan, penggunaan lahan dan jarak dengan pemukiman. Terakhir, indeks daya adptif (IAC) dibangun menggunakan parameter habitat pesisir, terumbu karang, mangrove, lamun dan kawasan konservasi. 
Berdasarkan hasil analisis menggunakan model pada Gambar 1, penelitian ini menunjukkan dimensi keterpaparan (exposure) meningkatkan nilai indeks kerentanan pantai di Pulau Poteran, sedangkan dimensi daya adaptif (adaptive capacity) Pulau Gili Lawak berperan dalam peningkatan nilai indeks kerentanan. Parameter kerentanan dalam dimensi keterpaparan (exposure) yang bersifat di Pulau Poteran dan Gili Lawak adalah kenaikan muka laut dan tingkat erosi. Kedua parameter tersebut memiliki skor yang tertinggi (Tabel 2), sehingga berperan meningkatkan nilai indeks keterpaparan.
Berdasarkan pengkalian bobot dan skor, kedua parameter tersebut menempati urutan teratas yang memberikan dampak terhadap peningkatan nilai indeks kerentanan pantai di Pulau Poteran. Hal ini berbeda dengan Pulau Gili Lawak yang menempatkan dimensi daya adaptif memberikan dampak tertinggi dalam peningktan indeks kerentanan pantai. Ketidakberadaan ekosistem lamun di Pulau Gili Lawak menyebabkan nilai indeks kerentanan pada dimensi daya adaptif menjadi lebih tinggi dari dimensi yang lain. Proyeksi kerentanan Pulau Poteran dan Gili Lawak selama 30 tahun tersaji pada Gambar 2 dan 3.

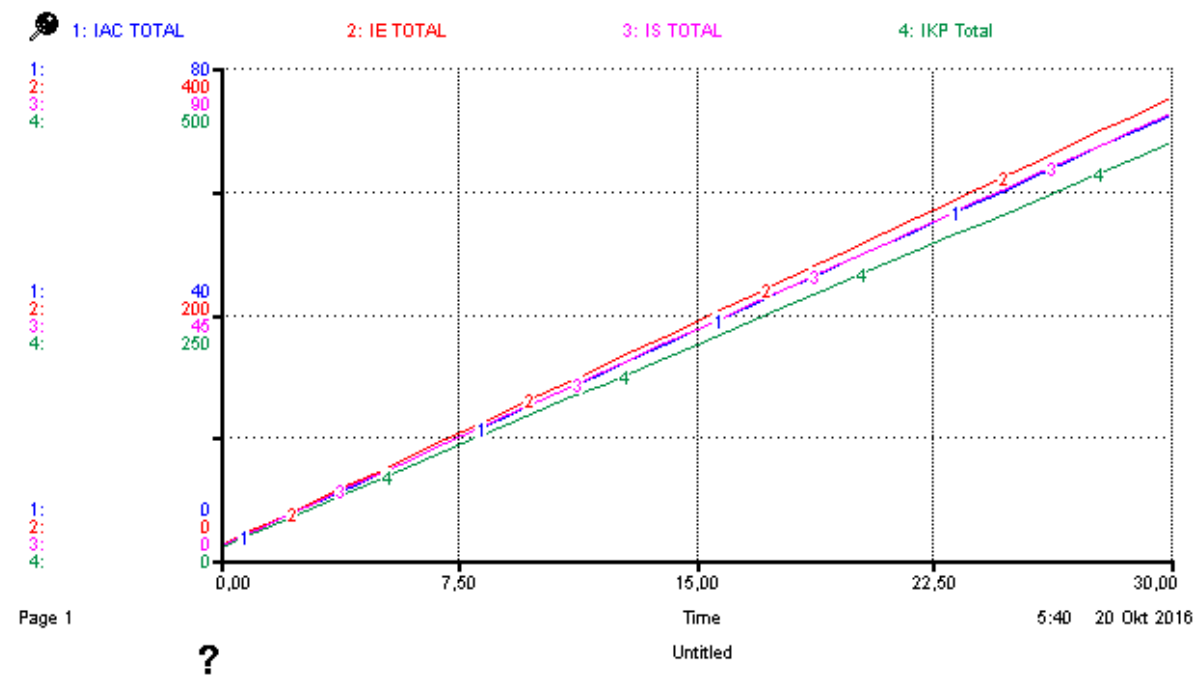

Gambar 2. Proyeksi Kerentanan Pulau Poteran selama 30 Tahun

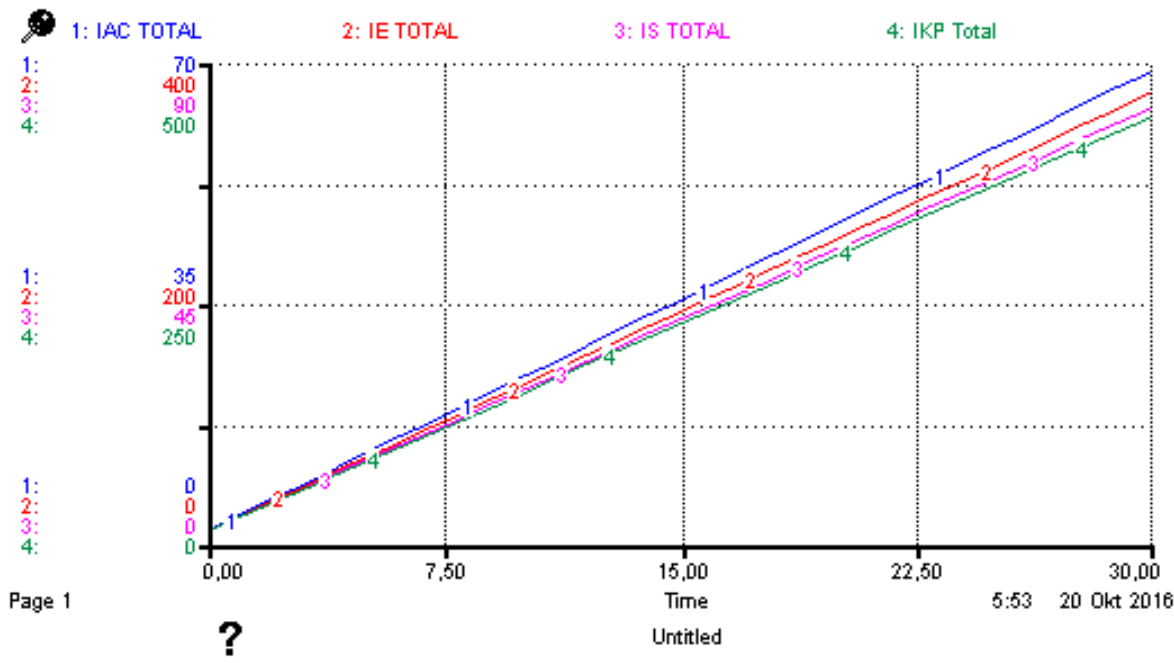

Gambar 3. Proyeksi Kerentanan Pulau Gili Lawak selama 30 Tahun 
Gambar 2 dan 3 menunjukkan setiap indeks yang membangun tingkat kerentanan pantai di Pulau Poteran dan Pulau Gili Lawak tanpa pengelolaan terus mengalami kenaikan. Indeks dengan nilai tertinggi adalah indeks keterpaparan (exposure) di Pulau Poteran dan indeks daya adaptasi (adaptive capacity) di Pulau Gili Lawak.

Analisis dinamika kerentanan ini menggunakan perubahan faktor-faktor eksternal yang dinamis dan mengalami peningkatan sehingga memberikan dampak terhadap sistem pulau-pulau kecil. Berdasarkan grafik di atas, tingkat kerentanan Pulau Poteran dan Pulau Gili Lawak saat ini berada pada kategori sedang pada saat ini dan akan terus mengalami peningkatan nilai kerentanan menjadi kategori tinggi dan sangat tinggi sampai tahun ke 30 .

Nilai kerentanan Pulau Poteran dan Gili Lawak diprediksi mengalami peningkatan dan masuk pada kategori sangat tinggi pada tahun ke tiga. Kondisi ini akan semakin meningkat tanpa adanya perlakuan atau pengelolaan yang dapat mengurangi peningkatan kerentanan pantai pulau-pulau kecil.

Salah satu upaya yang dapat dilakukan untuk mengurangi tingkat kerentanan pulau-pulau kecil adalah meningkatkan nilai adaptive capacity melalui pembangunan kawasan konservasi serta perlindungan dan perbaikan habitat pesisir sehingga dapat mengurangi nilai exposure serta sensitivity. Kapasitas adaptif dalam konteks pengelolaan pesisir dan pulau-pulau kecil merupakan kemampuan dari suatu kelompok untuk mengantisipasi dan merespon terhadap perubahan yang terjadi pada ekosistem pesisir (mangrove, terumbu karang dan lamun) untuk meminimalisasi dan memulihkan dari berbagai konsekuensi (McClanahan et al., 2008). Habitat pesisir juga memiliki peran dalam mencegah erosi dan menjaga stabilitas sedimen di sekitar pantai karena dalam proses sedimentasi sekitar $40 \%$ dari sedimen yang mengalir ke kawasan mangrove terperangkap dalam ekosistem mangrove (Victor et al., 2006). Dengan demikian, semakin luas ekosistem pesisir di pulau-pulau kecil, semakin besar kapasitas adaptif dari pulau tersebut (Tahir, 2010), sehingga pengelolaan terbaik untuk meningkatkan ketahanan dari sistem pulau- pulau kecil adalah mereduksi kerentanan lingkungan dan sosial (Mimura, 1999).

\section{KESIMPULAN DAN SARAN}

1. Terdapat 17 parameter yang terbagi atas tiga dimensi yang menetukan tingkat kerenatana pantai pulau-pulau kecil di Kecamatan Talango Kabupaten Sumenep. Dimensi keterpaparan (exposure) terdiri dari 3 (tiga) komponen yaitu: 1) dinamika pesisir; 2) gangguan alam; dan 3) penduduk. Selanjutnya, dimensi kepekaan (sensitivity) terdiri dari 3 (tiga) komponen yaitu: 1) karakteristik pantai; 2) penggunaan lahan; dan 3) pemukiman. Terakhir, dimensi daya adaptasi (adaptive capacity) terdiri dari dua komponen yaitu: 1) habitat pesisir (ekosistem terumbu karang, padang lamun dan mangrove); dan 2) kawasan konservasi.

2. Parameter kenaikan muka laut rata-rata tiap tahun, tingkat erosi dan kepadatan penduduk merupakan parameter dinamik yang menyebabkan nilai kerentanan tinggi di Pulau Poteran, sedangkan parameter lamun mengakibatkan dimensi daya adaptif diPulau Gili Lawak menjadi lebih tinggi dari dimensi yang lain.

3. Tingkat kerentanan pantai Pulau Poteran dan Gili Lawak berada pada kategori sedang dan berdasarkan model dinamik yang dibuat kedua pulau tersebut akan berada pada tingkat kerentanan sangat tinggi pada tahun ke 3 jika tidak dilakukan peningkatan kapasitas adaptif habitat pesisir.

\section{DAFTAR PUSTAKA}

Adrianto. (2005). Valuasi Ekonomi Sumberdaya Pulau-pulau Kecil: Sebuah Konsepsi EcologicalEconomics. In Working Paper Kebijakan Pengelolaan Perikanan dan Wilayah Pesisir tahun 2005. Adrianto L (Eds). Pusat Kajian Sumberdaya Pesisir dan Lautan IPB.Bogor. Part-7.

Doukakis, E. (2005). Coastal vulnerability and risk parameter. European Water, 11(12).

McClanahan, T. R., Cinner, J. E., Maina, J., Graham, N. A. J., Daw, T. M., Stead, S. M., Wamukota, A., 
Brown, K., Ateweberhan, M., Venus,

V., \& Polunin, N. V. C. (2008). Conservation action in a changing climate. Conservation Letter, 1, 5359.

Mimura, N. (1999). Vulnerability of island countries in the South Pacific to sea level rise and climate change. Climate Research, 12, 137-143.

Polsky, C., Neff, R., \& Yarnal, B. (2007). Building Comparable Global Change Vulnerability Assessments: The Vulnerabilitys Coping Diagram. Global Environmental Change, 17, $472-485$.

Pratt, C. R., Kaly, U. L., \& Mitchell, J. (2004). Manual: How to use the Environmental Vulnerability Index (EVI). SOPAC Technical Report 383: 60. United Nations Environment Program (UNEP). South Pacific Applied Geoscience Commission (SOPAC).

Rao, K. N, Subra, Elu, P., Rao, T. V., Malini, B. H., Ratheesh, R., Bhattacharya, S., Rajawat, A. S., \& Ajai. (2008). Sea level rise and coastal vulnerability: an assessment of Andhara Pradesh Coast, India through remote sensing and GIS. J. Coast. Conser., 12.

Tahir, A., Mennofatria, B., Susilo, B. D., \& Jaya, I. (2009). Indeks Keretanan Pulau-pulau Kecil: Kasus Pulau Barrang Lompo Makasar. Jurnal Ilmu Kelautan, 14(4), 8-13.

Tahir, A. (2010). Formulasi Indeks Kerentanan Lingkungan PulauPulau Kecil Kasus Pulau Kasu-Kota Batam, Pulau Barrang Lompo-Kota Makasar, dan Pulau SaonekKabupaten Raja Ampat. [Disertasi] Institut Pertanian Bogor. [Tidak Dipublikasikan].

Victor, S., Neth, L., Golbuu, Y., Wolanski, E., \& Richmond, R. H. (2007). Sedimentation in mangroves and coral reefs in a wet tropical island, Pohnpei, Micronesia. Estuarine, Coastal and Shelf Science, 66, 409416. 